\title{
МОНГОЛ-ГЕРМАНЫ ХАМТАРСАН ЧУЛУУН ЗЭВСГИЙН СУДАЛГААНЫ АНГИЙН 2012 ОНД ХИЙСЭН МАЛТЛАГА СУДАЛГААНЫ УРЬДЧИЛСАН ҮР ДУН
}

\author{
Б.Гүнчинсүрэн ${ }^{1}$, Ц.Болорбат ${ }^{2}$, Н.Звинс \\ ${ }^{1,2}$ ШУА, Археологийн хүрээлэн, \\ ${ }^{3}$ Max-Planck Institute, Germany \\ Цахим шуудан: bgunchinsuren@yahoo.com
}

Монгол-Германы хамтарсан чулуун зэвсгийн судалгааны ангийнхан 2012 онд Булган аймгийн Хутаг-Өндөр сумын нутагт орших олон соёлт давхарга бүхий “Төлбөр16" палеолитын дурсгалт газарт малтлага судалгааны ажил хийж гүйцэтгэсэн. Төлбөр16 дурсгалт газар нь Уньт багийн төвөөс зүүн тийш 10 орчим км, Их Төлбөрийн голын хойд талд араараа модтой өндөр уулсын урд талын томоохон дэвсэг дээр оршино. УГ дэвсэг нь урагшаа бага зэрэг налуу нилээд том талбайтай бөгөөд баруун талаараа гүн жалгатай ажээ. Энэ дэвсэг дээр мөн хэд хэдэн хиргисүүр бий.

Булган аймгийн Хутаг-Өндөр сумын нутаг Төлбөрийн голын хөндийгөөс анх 1975 онд Монгол-Зөвлөлтийн түүх, соёлын хамтарсан экспедицийн чулуун зэвсгийн судалгааны ангийнхан цөөн тооны чулуун зэвсэг түүвэрлэн цуглуулсан ажээ [Цэвээндорж., 1975].

Монгол-Оросын хамтарсан хээрийн шинжилгээний анги нь “Төв Монголын чулуун зэвсгийн үе” төслийн хүрээнд 2002 онд Улаанбаатараас Хөвсгөл нуур хүртэл хийсэн хайгуул судалгааны явцад Булган аймгийн Хутаг-Өндөр сумын нутагт орших Төлбөрийн голын хөндийд нарийвчилсан явган хайгуул хийж, чулуун зэвсгийн 14 суурин илрүүлж, 1000 орчим чулуун зэвсгийн олдвор түүвэрлэн цуглуулсан юм.

2004-2006 оны хооронд МонголОросын хамтарсан хээрийн шинжилгээний ангийнхан Төлбөр-4 палеолитын дурсгалт газарт нийт $67 \mathrm{~m}^{2}$ талбайд малтлага судалгааг гүйцэтгэж, нийт 25907 ш чулуун зэвсгийн олдвор олж илрүүлсэн юм
[Деревянко, Олсен, Цэвээндорж и др., 2005; Деревянко, Зенин и др., 2006; Деревянко, Цэвээндорж, Цэрэндагва нар., 2006]. Малтлагын явцад Төлбөр-4 дурсгалын 6-р давхаргаас илэрсэн ясан эдлэлд хийсэн радиокарбоны шинжилгээгээр $37.400 \pm 2600$ (АА79314, АНУ) жилийн тэртээд, 5-р давхаргаас илэрсэн тэмээн хяруулын өндөгний хальсанд хийсэн радиокарбоны шинжилгээгээр 26.700 \pm 300 (АА84135, АНУ) жилийн тэртээд холбогдоно хэмээн гарчээ.

2006 онд Монгол-Оросын хамтарсан хээрийн Төлбөр-4 дурсгалт газар малтлага судалгаа хийх явцдаа ойр орчимд хайгуул хийж бидний малтлагаас дээш 1.5 км-ийн зайд автозам засах шороо авсан ухмалын үлдэгдэл хананаас хөрсний хэд хэдэн үед байрлах чулуун зэвсгийн олдвор буйг доктор Е.П.Рыбин анх илрүүлсэн. 2008-2011 оны хооронд энэхүY дурсгалт

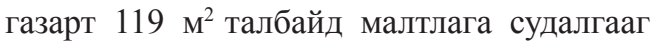
гүйцэтгэж, нийтдээ 33386 ш чулуун зэвсгийн олдвор олж илрүүлсэн байна [Гүнчинсүрэн, Гладышев нар., 2008; 2009; 2010; 2011]. Төлбөр-15 дурсгалт газрын 7-p давхаргаас илэрсэн тэмээн хяруулын өндөгний хальсанд хийсэн он цаг тогтоох радиокарбоны шинжилгээгээр 29.150 320 (АА 84138, АНУ) жилийн тэртээд, 5-p давхаргаaс илэрсэн тэмээн хяруулын өндөгний хальсанд хийсэн радиокарбоны

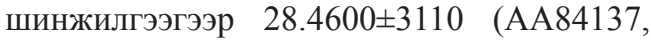
АНУ)жилийнтэртээд,4-рдавхаргаасилэрсэн тэмээн хяруулын өндөгний хальсанд хийсэн радиокарбоны шинжилгээгээр 14.820土70 (Beta263745, АНУ) жилийн тэртээд, мөн 
3-р давхаргаас илэрсэн тэмээн хяруулын өндөгний хальсанд хийсэн радиокарбоны шинжилгээгээр 14.056 \pm 81 (АА84136, АНУ) жилийн тэртээд буюу Төлбөр-4 дурсгалаас арай хожуу үед холбогдох нь тодорхой болжээ.

Монгол-Оросын хамтарсан хээрийн шинжилгээний ангийнхан Төлбөрийн голын дурсгал газарт малтлага хийх явцдаа голын хөндийн дагуу хайгуул хийж, нийтдээ чулуун зэвсгийн 29 дурсгалт газар илрүүлэн олж тэмдэглэсэн байна [Гунчинсурэн, Гладышев и др., 2011]. Мөн Төлбөрийн голоос баруун тийш холгүйхэн орших Сэлэнгэ мөрний дунд урсгал орчимд малтлага хийжээ [Zwins, Gladyshev et all., 2011].

\section{2 оны малтлага судалгаа}

2012 онд Монгол-Германы хамтарсан судалгааны анги уг дурсгалт газар өмнөх онуудад тандалт хийсэн 6 м² талбайг хойд тал руу нь сунгаж, 5 м² талбайд малтлага судалгааны ажил хийж гүйцэтгэв (Зураг 1). Малтлагын явцад хөрс судлал болон эрдэс судлалын харьцуулсан судалгаа хийж хөрсний бүтэц, насыг тодорхойлох хийх зорилгоор хөрсний давхаргуудаас дээж авсан.

Малтлагын талбайн ханын зүсэлтээс ажиглахад хөрсний 7 давхаргатай болох нь тодорхой болж байна (Зураг 2).

1-p давхарга. Ширэг (хөрс, ургамал) зонхилсон ялзмагжсан хүрэн өнгийн хөрстэй ба зузаан нь харилцан адилгүй (0.00.25 м) байна.

2-p давхарга. Хар хүрэн өнгийн нягт, жижиг ширхэг бүхий хөрстэй, зузаан нь 0.25-0.55 м байна.

3-p давхарга. Цайвар бор өнгөтэй химэрлэг хөрстэй, зузаан нь 0.55-0.85 м байна.

4-p давхарга. Цайвар өнгийн химэрлэг, элсэнцэр хөрстэй. Доод хязгаар нь тэгш бус, зузаан нь 0.85-1.40 м байна.

5-6-рдавхарга. Шаргалөнгийнэлсэрхэг- цутгах Хануй голын адаг орчимд, мөн түүнд цутгах жижиг голуудын хөндийгөөр чулуун зэвсгийн хайгуул судалгаа хийж, шинээр хэд хэдэн дурсгалт газрыг илрүүлэн нийт 191 ш чулуун зэвсгийн олдвор түүвэрлэн цуглуулжээ [Гладышев и др., 2007].

Монгол-Оросын хамтарсан “Төв Монголын чулуун зэвсгийн үе" төслийн хүрээнд 2010 онд “Төлбөр-15” дурсгалт газар малтлага судалгаa хийх явцдаа Төлбөрийн голын хөндийн ойр орчимд нь хайгуул судалгаа явуулж “Төлбөр-16" дурсгалт газрыг шинээр илрүүлэн 2010, 2011 онуудад багахан хэмжээний тандалтын

шавранцар зузаан давхарга бүхий хөрстэй. Энэхүу нягт, нүхлэг хананд жижгэвтэр хайрга болон цул чулуу шигджээ, зузаан нь 1.40-1.65 м. Эдгээр давхаргын хоорондын зааг зарим газраа бараг мэдэгдэхгүй ажээ.

7-p давхарга. Цайвар өнгийн элсэрхэг хөрстэй, зузаан нь 1.65-2.10м. ЭнэхүY давхарга дотроо бага зэргийн ялгаатай байсан тул 7a, 76 гэж хуваав.

Уг дурсгалт газарт малтлага хийх явцад эхний 3-н давхаргаас маш цөөхөн тооны чулуун зэвсгийн олдвор илэрсэн бөгөөд 4-p давхаргаас эхлэн олдворын тоо харьцангуй олширч байгаа нь сонирхолтой (Зураг 3). Эндээс нийтдээ 3664 ш чулуун зэвсгийн олдвор илрүүлснээс:

• 1011 ш чулуун зэвсгийн олдвор (малтлагаас)

• 3664 ш чулуун эзвсгийн хэлтэрхий (шигшүүрээс)

- 27 ш амьтны шүд, яс, ясны үлдэгдэл

- 2 ш ваарны хагархай (малтлагаас) зэрэг илрэв.

Тус дурсгал газраас илэрсэн чулуун зэвсгийн олдворуудад бэлдэц 61 ш, үлдэц 364 ш, зэвсэгийн төрлийн эдлэл 64 ш, залтас 29 ш, ялтас 395 ш, үлдсэн нь цуулдасны үйлдвэрлэлийн явцад гарсан 
хэлтэрхий байна. Үлдэцнүүдийн дотор дээд палеолитын эхэн шатны бүхий л шинж төрхийг илтгэсэн цохилтын хоёр талбайт, цуулалтын хоёр гадаргуутай хавтгай үлдэцнүүд (Зураг 4. 6, 7), мөн дээд палеолитын сүүлийн хагаст холбогдох бичил ялтас цуулахад зориулагдсан тайрдсан үлдэцнүүд ч багагүй байна (Зураг 4. 1, 2, 3, 4). Багаж зэвсгийн дунд хусуур,

\section{ДҮГНЭЛТ}

2011 онд Төлбөр-16 чулуун зэвсгийн дурсгалт газрын хөрсний 7-р давхаргаaс илэрсэн галын оромны дээжинд хийсэн он цаг тогтоох шинжилгээгээр (цацраг идэвхэт нүур хүчлийн) $33.320 \pm 180$ (REVA-237) жилийн тэртээд холбогдож байгаа бол хөрсний 4-р давхаргаас илэрсэн ясны үлдэгдэлд хийсэн он цаг тогтоох лабораторийн шинжилгээгээр $15.660 \pm 40$ (R-EVA-243) жилийн тэртээд холбогдоно хэмээн тогтоожээ.

2012 оны малтлагаар Төлбөр-16 палеолитын дурсгалт газраас илэрсэн үлдэцнүүдийн ерөнхий шинж төрх, цуулалтын аргын хувьд зарим тохиолдолд Төлбөр-4 [Деревянко, Олсен, Цэвээндорж.,

\section{Resume}

Mongolian and Germany joint expedition started research excavation at the "Tulbur-16" Paleolithic site in 2012. The excavation covered totally 5 sq.m. In the result of the excavation, there stratigraphic has seven layers and 3664 stone tools are found. The knapping technique of some of the findings are similar to findings хянгар, шүдлэг-хүнхэр зэвсэг болон хатгуур маягийн зэвсэг олон тоотой байна (Зураг 5). Цуулдасны үйлдвэрлэлд хамгийн олон тоотой хэлтэрхий байгаа ба ялтас цөөнгүй хувийг бүрдүүлж байна (Зураг 6).

Мөн хөрсний 7-р давхаргаас хоёр галын ором илэрсэн бөгөөд багахан хэмжээтэй, нилээд нимгэн ажээ.

2006] палеолитын дурсгалт газрын доод давхаргуудаас илэрсэн үлдэцнүүдтэй ижилсэж байгаa нь дээд палеолитын эхэн үед холбогдох болохыг тодорхой болгож байгаа бөгөөд цуулалтын аргын хувьд хавтгай болон призм хэлбэрийн үлдэцнүүдэд изохилтын арга давамгайлж байсан бол хожим нь бичил цуулалтанд зориулагдсан шахалтын арга луу аажмаар шилжсэн нь бичил хэмжээтэй үлдэц, цуулдас олширсноор тодорхойлогдож байна. Эдгээр дүгнэлтүүдээс үзэхэд нь энэхүҮ дурсгалт газар нутагт эртний хүн дээд палеолитын эхэн үеэс сүүл үе хүртэл урт удаан хугацааны туршид суурьшин амьдарч ирснийг нотлон харуулж байна.

from lower layers of Tulbur-4 and Tulbur- 15 sites. This result is definitelly indicating that this site belongs to Upper Paleolithic and it is representing that ancient human were settled in this region for longer period: from early to finality of Upper Paleolithic. 


\section{Ашигласан бүтээлийн жагсаалт}

1. Гунчинсүрэн, Гладышев и др., 2008 - Гүнчинсүрэн Б., Гладышев С.А., Болорбат Ц., Цыбанков А.А., Одсүрэн Д., Чаргынов Т.Т. Археологическое изучение многослойного палеолитического памятника Толбор- 15 в 2008 году. Археологийн судлал. XXV. УБ. - 5-26 тал.

2. Гунчинсурэн, Гладышев и др., 2009 - Гунчинсурэн Б., Гладышев С.А., Табарев А.В., Болорбат Ц., Одсурэн Д. Голоценовый комплекс стоянки Толбор-15 (северная Монголия). //Проблемы археологии, этнографии, антропологии Сибири и сопредельных территорий - Новосибирск: Изд-во ИАЭТ СО РАН, 2009a. T. XV, - 79-83 c.

3. Гунчинсурэн, Гладышев и др., 2010 - Гунчинсурэн Б., Гладышев С.А., Болорбат Ц., Табарев А.В., Одсурэн Д., Цыбанков А.А., Чаргынов Т.Т. Новые данные по изучению многослойного палеолитического памятника Тулбэр-15 в 2009 году. Археологийн судлал. ХХІХ. УБ. - 5-31 тал.

4. Деревянко, Олсен, Цэвээндорж., 2005 - Деревянко А.П., Цэвээндорж Д., Олсен Д., Гунчинсурэн Б., Зенин А.Н., Гладышев С.А., Рыбин Е.П., Цыбанков А.А., Чаргынов Т.Т., Кандыба А.В. Раскопки многослойного поселения Толбор-4 в 2005 г. //Проблемы археологии, этнографии, антропологии Сибири и сопредельных территорий (Материалы Годовой сессии Института археологии и этнографии СО РАН. Декабрь 2005 г.). Новосибирск. Т. XI.

5. Деревянко, Зенин и др., 2006 - Деревянко А.П., Зенин А.Н., Рыбин Е.П., Гладышев С.А., Цыбанков А.А. Развитие каменных индустрий верхнего палеолита Северной Монголии (по данным стоянки Толбор). //Человек и пространство в культурах каменного века Евразии. - Новосибирск, с. 17-42

6. Деревянко, Цэвээндорж, Цэрэндагва нар., 2006 - Деревянко А.П., Цэвээндорж Д., Цэрэндагва Я., Гладышев С.А., Болорбат Ц., Рыбин Е.П., Чаргынов Т. Булган аймгийн Хутаг-Өндөр сумын нутаг Төлбөрийн голд Монгол-Оросын хамтарсан археологийн хээрийн шинжилгээний ангийн хийсэн археологийн малтлага судалгааны ажлын тайлан. УБ., 2006

7. Zwins, Gladyshev, Tabarev - N.Zwins., S.A.Gladyshev., A.V.Tabarev. The Upper Paleolithic of the Ikh-Tulberin-Gol: a report on the 2011 excavations at Tolbor 16 site, Northern Mongolia.

8. Цэвээндорж., 1975 - Цэвээндорж Д. 1975 онд МЗТСХЭ-ийн Булган, Хөвсгөл, Увс, Архангай, Баянхонгор аймагт ажилласан палеолит ба нүүдэлчдийн дурсгал судлах ангийн тайлан. //АХГБС. 
Tolber 16 - pit 1

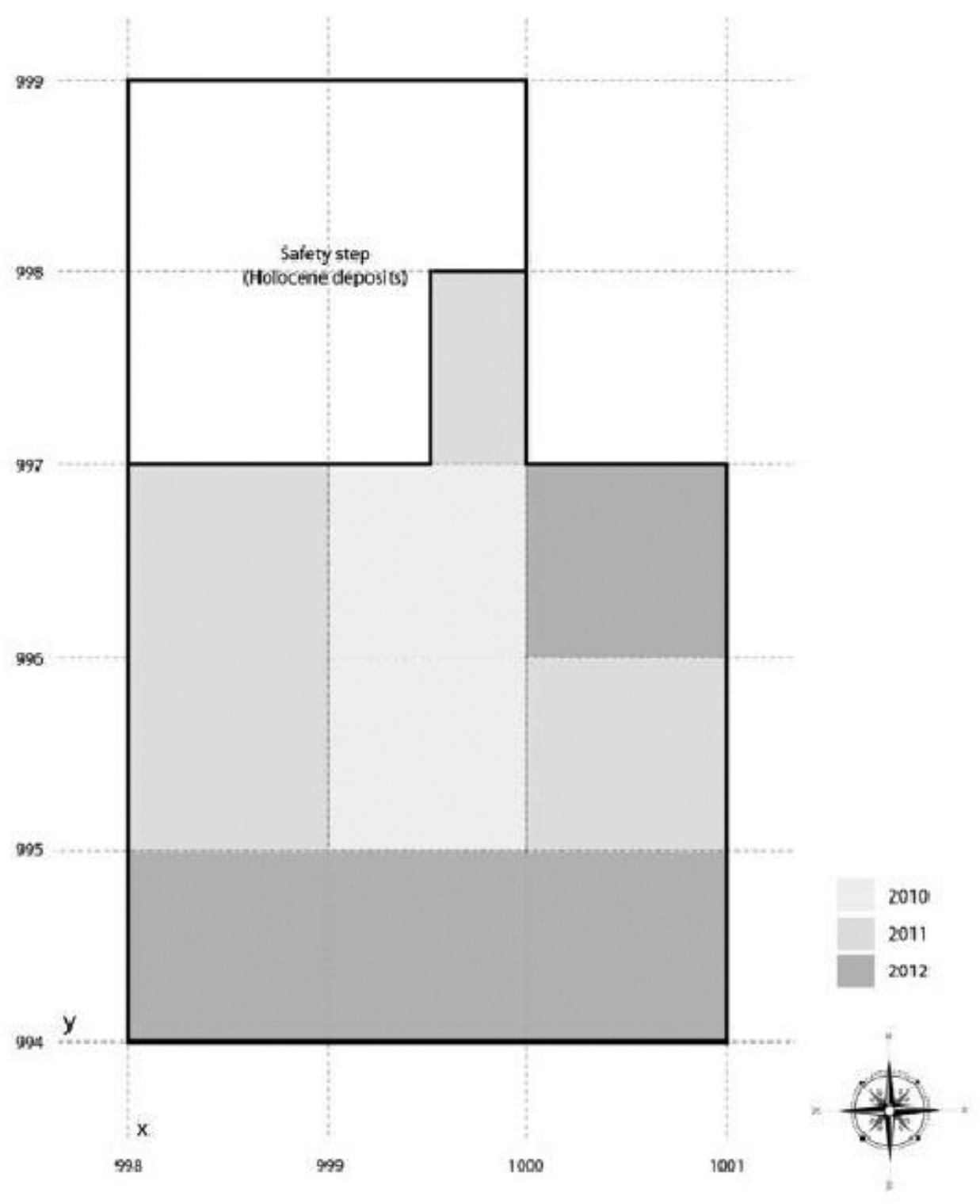

Зураг 1. Малтлагын талбайн зураг 


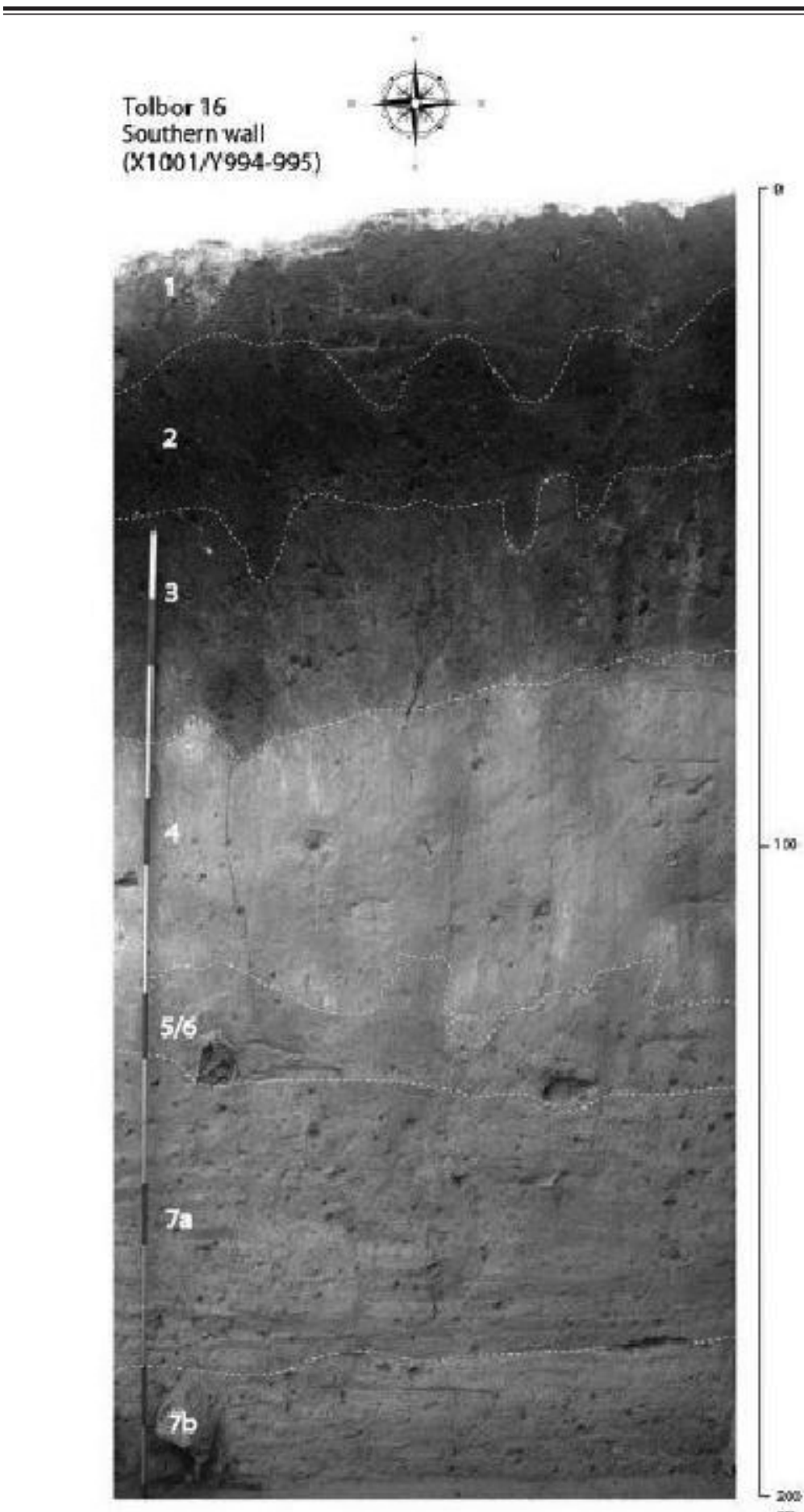

Зураг 2. Ханын зүсэлтийн зураг 


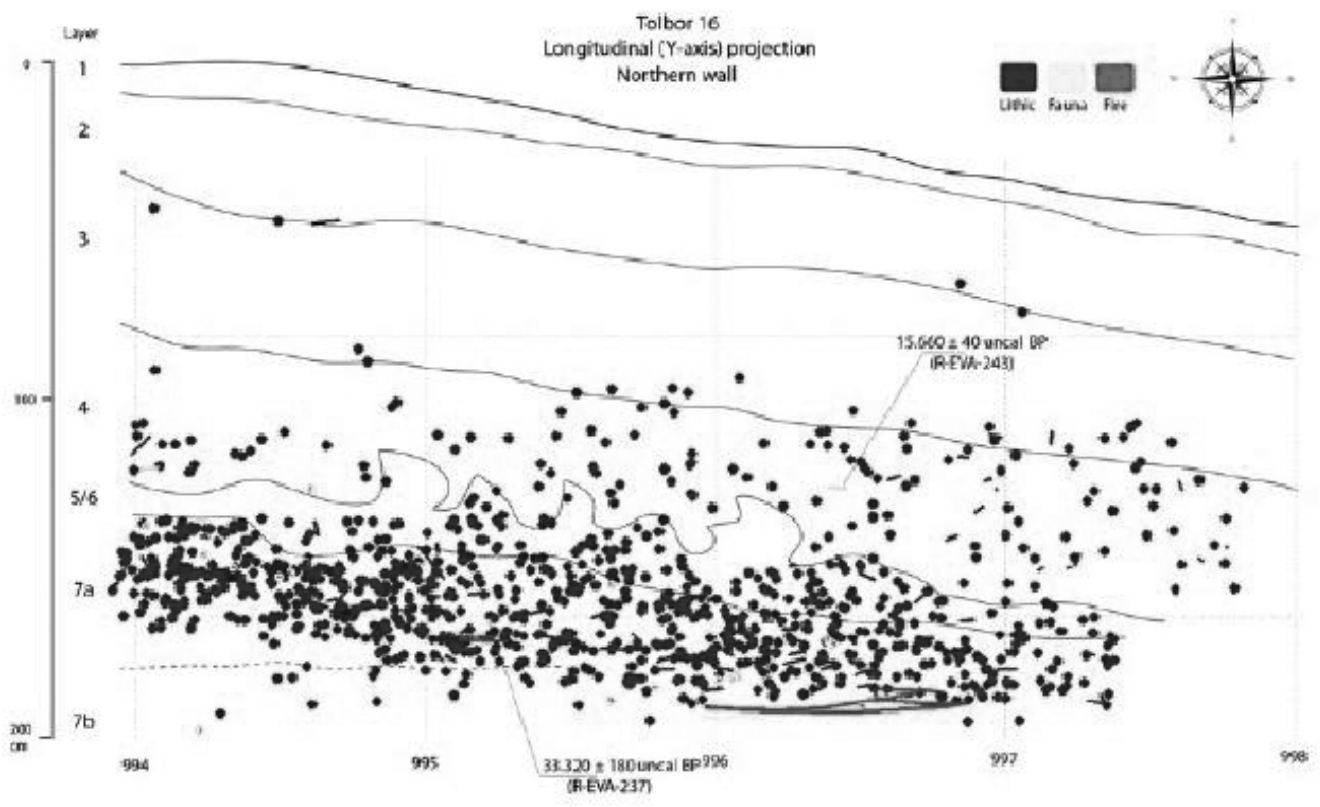

Зураг 3. Олдворуудын байршлыг харуулсан зураг
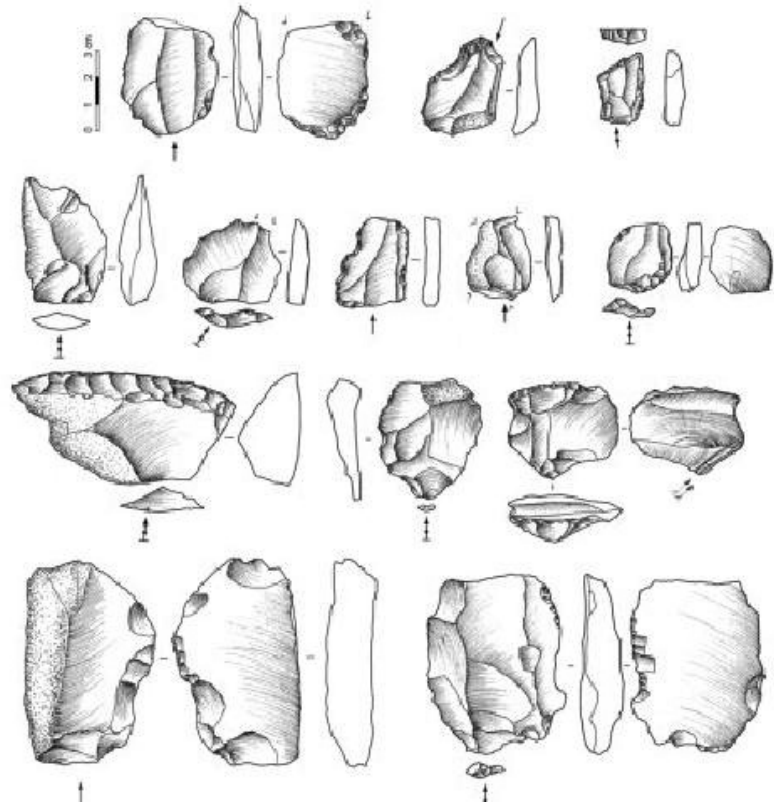

Зураг 4. Төлбөр-16 дурсгалаас илэрсэн үлдэцнүүдээс 

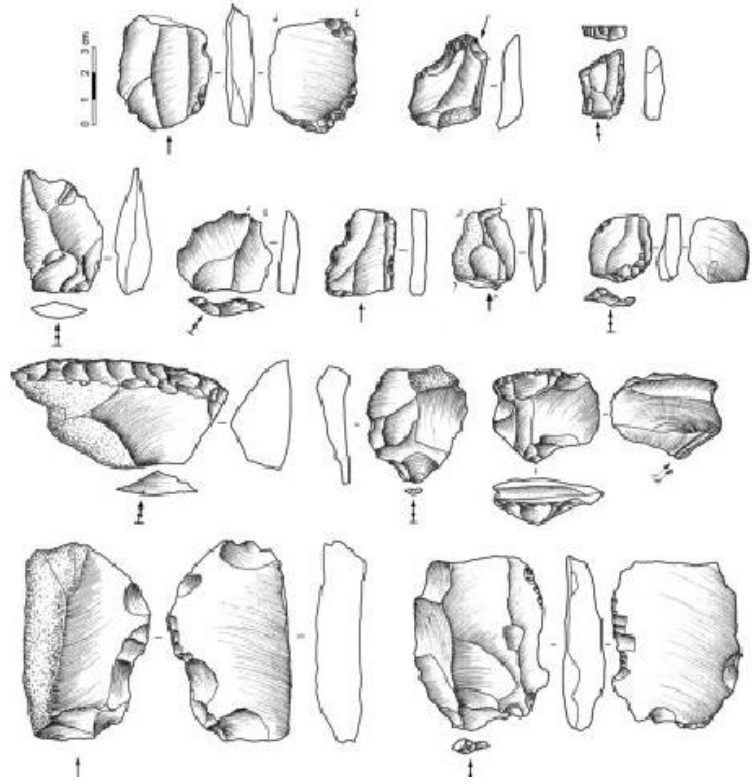

Зураг 5. Төлбөр-16 дурсгалаас илэрсэн зэвсгүүдээс
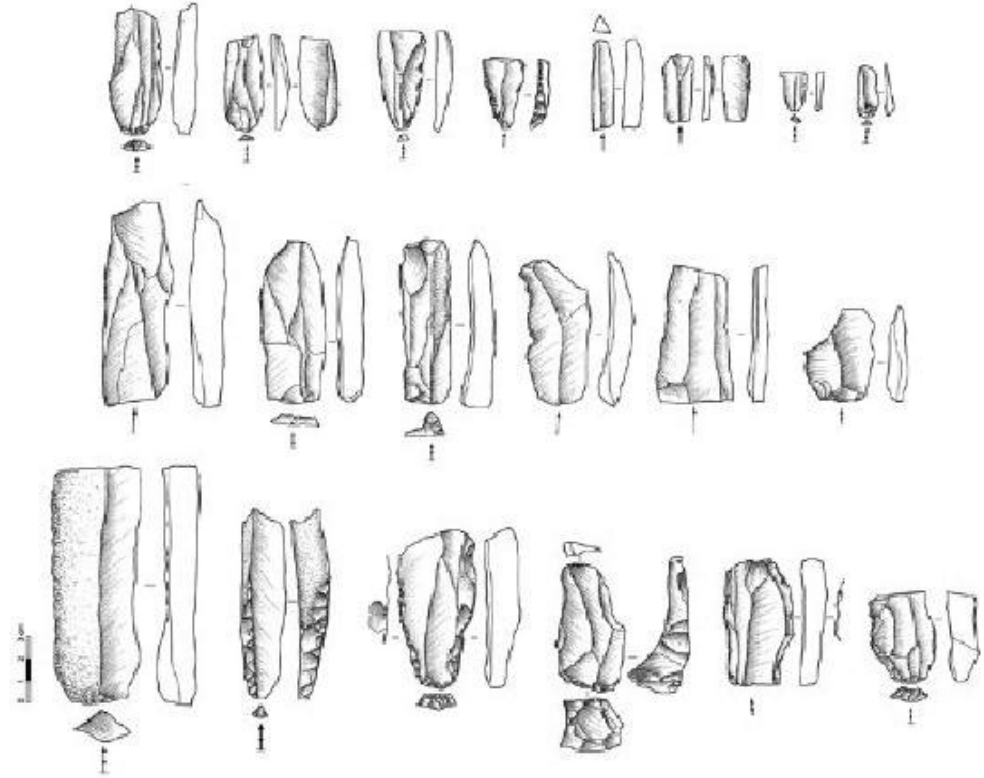

Зураг 6. Төлбөр-16 дурсгалаас илэрсэн цуулдаснууд 